Jurnal Manajemen Bisnis dan Manajemen Informatika

Journal homepage: www.jurnal.stie-mandala.ac.id

E-ISSN 2774 - 2229

\title{
Analisa Kepuasan Pelanggan Pengangkutan Sampah Menggunakan Metode Importance Performance Analysis (Studi Kasus Pada Dinas Lingkungan Hidup Kabupaten Jember)
}

\author{
Harvian Bagus Dewantara $^{a}$, Hary Sulaksono ${ }^{b}$ \\ ${ }^{a}$ Mahasiswa STIE Mandala Jember \\ ${ }^{b}$ Dosen STIE Mandala Jember, hary@stie-mandala.ac.id \\ E-mail Penulis Korespondensi : hary@stie-mandala.ac.id
}

I N F O A R T I K E L

Riwayat Artikel:

Dikirim 17 Februari 2021

Direvisi 18 Maret 2021

Diterima 10 April 2021

Keywords:

Tangibles,

Responsiveness,

Assurance and emphaty.

\section{Kata Kunci:}

Bukti Fisik (Tangibles),

Kehandalan (Reliability),

Daya Tanggap

(Responsiveness),

Jaminan (Assurance), dan Empati (Emphaty).

\section{A B S T R A C T}

This study aims to determine what quality dimension attributes have met customer satisfaction for waste transportation of the Department of the Environment of Jember Regency. The data used in this study are primary data. The data processing method in this study uses the Data Instrument Test Analysis method, namely: Validity Test and Reliability Test, and uses the Importance Performance Analysis (IPA) analysis method, using 5 service quality dimension attributes, namely Physical Evidence (Tangibles), Reliability (Reliability), Responsiveness, Assurance, and Empathy (Emphaty). The results showed that the Reliability Dimension has a very low gap value, which indicates that the quality of service provided by the Environmental Service Office of Jember Regency is very satisfying for customers. Meanwhile, the dimension of responsiveness has the highest gap, which can be concluded that there is dissatisfaction for customers with the responsiveness of the Jember Regency Environmental Service in dealing with existing problems. This of course will become a reference for the Jember Regency Environmental Service in improving the quality of its services. 


\section{A B S T R A K}

Penelitian ini bertujuan untuk mengetahui atribut dimensi kualitas apa saja yang telah memenuhi kepuasan pelanggan pengangkutan sampah Dinas Lingkungan Hidup Kabupaten Jember. Data yang digunakan dalam penelitian ini berupa data Primer. Metode pengolahan data pada penelitian ini menggunakan metode Analisis Uji Instrumen Data yaitu: Uji Validitas dan Uji Reliabilitas, dan menggunakan metode analisis Importance Performance Analysis (IPA), dengan menggunakan 5 atribut dimensi kualitas pelayanan yaitu Bukti Fisik (Tangibles), Kehandalan (Reliability), Daya Tanggap (Responsiveness), Jaminan (Assurance), dan Empati (Emphaty). Hasil penelitian menunjukkan bahwa Dimensi Kehandalan memiliki nilai kesenjangan yang sangat rendah, yang menandakan bahwa kualitas pelayanan yang diberikan oleh Dinas Lingkungan Hidup Kabupaten Jember sangat memuaskan bagi pelanggan. Sedangkan pada Dimensi Daya Tanggap memiliki kesenjangan paling tinggi, yang dapat disimpulkan bahwa terdapat ketidak puasan bagi pelanggan terhadap ketanggapan Dinas Lingkungan Hidup Kabupaten Jember dalam menangani permasalahan yang ada. Hal ini tentu saja yang akan menjadi acuan untuk Dinas Lingkungan Hidup Kabupaten Jember dalam memperbaiki kualitas pelayananya.

\section{PENDAHULUAN}

Pesatnya perkembangan pembangunan wilayah perkotaan khususnya di Kota Jember. Sebagai Kota yang cukup padat penduduk ini dan diikuti oleh pindahnya sebagian penduduk desa ke kota, tentunya sangat berdampak pada peningkatan jumlah penduduk kota yang juga sebanding dengan limbah yang akan dihasilkan. Namun, tidak disertai secara langsung dengan penyediaan sarana dan prasarana yang sebanding oleh pemerintah, akibatnya pelayanan yang ada tidak maksimal dan terjadi penurunan kualitas lingkungan, khususnya pada permasalahan pengangkutan sampah kota. Untuk menanggulangi permasalahan ini, sangat dibutuhkan peranan pemerintah yang didukung oleh kepedulian masyarakat kota setempat.

Berkaitan dengan pemenuhan kebutuhan masyarakat akan pelayanan yang semakin komplek, pemerintah sebagai penanggung jawab pelayanan dalam organisasi negara membentuk berbagai department atau instansi baik di pusat maupun daerah yang bertugas melayani masyarakat dalam memenuhi kebutuhan akan produk dan jasa. Salah satunya adalah terbentuknya Dinas Lingkungan Hidup sebagai perangkat daerah Pemerintah Kabupaten Jember yang merupakan sarana pelayanan kebutuhan masyarakat akan jasa 
pelayanan kebersihan.

Sampai saat ini pelayanan yang dilakukan pemerintah khususnya Dinas Lingkungan Hidup dalam hal pelayanan pengangkutan sampah masih belum maksimal. Sampah yang tidak terkelola dengan baik merupakan salah satu penyebab makin meningkatnya pencemaran air, tanah dan udara serta meningkatkan potensi banjir diperkotaan. Permasalahan persampahan perlu ditangani secara serius dengan teknis operasional dan manajemen yang tepat dan terpadu berdasarkan kondisi dan kebijakan daerah Kota Jember.

Peningkatkan pelayanan yang memuaskan masyarakat sudah menjadi keharusan bagi pemerintah untuk menyediakan dan memberikan pelayanan yang berkualitas kepada masyarakat. Hal tersebut merupakan salah satu bentuk fungsi pokok pemerintahan yaitu memberikan pelayanan (service delivery) selain pembangunan (development) dan pemberdayaan masyarakat (empowerment), (Rasyid, 1997:71).

Kepuasan pelanggan merupakan indikator utama dari standar suatu fasilitas dan sebagai suatu ukuran mutu pelayanan yang diberikan. Kepuasan pelanggan dapat dicapai melalui hasil kinerja terbaik dalam memberikan pelayanan kepada pelanggan. Pemberian pelayanan terbaik terjadi bila perusahaan mampu menjaga/meningkatkan kualitas jasa atau pelayanan yang diberikan kepada pelanggan. Oleh karena itu perusahaan harus dapat terus membaca apa yang menjadi kebutuhan pelanggan guna mencapai tingkat kepuasan pelanggan yang tinggi.Kepuasan pelanggan adalah salah satu kunci dalam menciptakan kepuasan pelanggan. Pentingnya kepuasan pelanggan dapat memberikan beberapa manfaat, diantaranya adalah hubungan antara perusahaan dan para pelanggannya menjadi harmonis, memberikan dasar yang baik untuk pembelian kembali, dapat mendorong terciptanya loyalitas pelanggan, dan timbulnya kesediaan pelanggan untuk membayar dengan harga yang wajar atas jasa yang diterimanya.

Operasional pelayanan pengangkutan sampah adalah pengangkutan sampah dari TPS yang telah disediakan Dinas Lingkungan Hidup, kemudian dari TPS (Tempat Pembuangan Sampah), sampah diangkut ke Tempat Pembuangan Akhir (TPA). Dalam penelitian ini penulis memfokuskan pada pelayanan pengangkutan sampah di TPS, yaitu khususnya pada pelayanan pengangkutan sampah dari pemukiman/penduduk yang diangkut oleh petugas kebersihan (swadaya/voluntary) RT/RW di wilayah kota Kabupaten Jember.

Tingginya kepadatan penduduk di wilayah perkotaan juga membuat tumpukan kian menggunung, sedangkan lahan untuk menampung sangat terbatas. Kepala Dinas Lingkungan Hidup Kabupaten Jember, Arismaya Parahita menyebutkan, tercatat saat ini masyarakat menghasilkan 1.350 ton sampah setiap harinya, dan hanya sekitar 400 ton saja 
yang sampai di 5 TPA yang ada. "Sisanya, berakhir di sungai-sungai atau laut. Dari 400 ton sampah tersebut, 85 persen ditampung di TPA Pakusari”. (Arismaya Parahita dalam Cendana News, 21/11/2018).

Berdasarkan permasalahan diatas cukup kiranya dijadikan dasar praduga bahwa pelayanan pengangkutan sampah DLH di Kabupaten Jember belum optimal kinerjanya. Oleh karena itu penulis tertarik untuk meneliti tentang pelayanan Pengangkutan Sampah yang baru dengan judul "Analisa Kepuasan Pelanggan Pengangkutan Sampah Menggunakan Metode Importance Performance Analysis (Studi Kasus Pada Dinas Lingkungan Hidup Kabupaten Jember).”

\section{TINJAUAN PUSTAKA}

\section{Definisi Manajemen Pemasaran}

Menurut American Marketing Association (AMA) (dalam Kotler dan Keller, 2009:05) mendefinisikan pemasaran adalah "suatu fungsi organisasi dan serangkaian proses untuk menciptakan, mengomunasikan, dan memberikan nilai kepada pelanggan dan untuk mengelola hubungan pelanggan dengan cara yang menguntungan organisasi dan pemangku kepentingannya”.

\section{Fungsi Manajemen Pemasaran}

Adapun fungsi pemasaran yang dikemukakan oleh Sudaryono (2016:50) sebagai berikut:

1. Fungsi pertukaran yaitu dengan ada pemasaran, maka pembeli dapat membeli produk yang dijual oleh produsen. Cara yang digunakan melalui pertukaran dengan uang maupun menukar produk dengan produk (barter) bertujuan dipakai sendiri maupun di jual kembali

2. Fungsi distribusi fisik suatu produk dilaksanakan dengan menyalurkan serta menyimpan barang. Produk disalurkan dari produsen untuk konsumen melalui air, udara dan darat. Penyimpanan produk berfokus pada upaya menjaga pasokan produk agar tidak kekurangan saat dibutuhkan.

3. Fungsi perantara untuk menyampaikan produk dari produsen kepada konsumen dapat dilakukan melalui pemasaran yang menggunakan aktivitas pertukaran dengan distribusi fisik.

\section{Konsep Manajemen Pemasaran}

Menurut Cooper P.D (1979:9), terdapat 4 konsep dalam pemasaran, yaitu : 
a. Konsep pelayanan, artinya orientasi hanya untuk memberikan pelayanan dan fasilitas yang baik.

b. Konsep penjualan, artinya orientasi hanya pada usaha untuk mencapai pemanfaatan fasilitas dengan memadai.

c. Konsep pemasaran, artinya orientasi berusaha untuk mengetahui keinginan dan kebutuhan pasien serta menciptakan pelayanan yang memuaskan.

d. Konsep pemasaran sosial artinya orientasi pada usaha untuk memenuhi kebutuhan, keinginan dan permintaan konsumen serta memberikan kepuasan. Konsep pemasaran sosial meyakini bahwa tugas perusahaan adalah menetapkan kebutuhan, keinginan, dan kepentingan pasar sasaran dan memberikan kepuasan yang diinginkan secara lebih efektif dan efisien daripada para pesaing dengan cara-cara yang menjaga atau meningkatkan kesejahteraan konsumen dan masyarakat.

\section{Konsep Kualitas Pelayanan}

Berkaitan dengan pelayanan Kotler (dalam Tjiptono, 2001:6) menyatakan bahwa, "tindakan atau perbuatan yang ditawarkan oleh semua pihak kepada orang lain yang pada dasarnya bersifat intangible (tidak berwujud fisik) dan tidak menghasilkan kepemilikian sesuatu. Produk jasa tersebut bisa berhubungan dengan produk fisik maupun tidak".

Sedangkan menurut pendapat Moenir (2002:16) disebutkan bahwa, "Pelayanan adalah proses pemenuhan kebutuhan melalui aktivitas orang lain yang dilakukan secara langsung”.

Dari kedua pengertian diatas dapat dikatakan bahwa pelayanan merupakan proses pemenuhan kebutuhan melalui aktivitas orang lain yang tidak berwujud fisik dan tidak menghasilkan kepemilikan sesuatu. Pelayanan merupakan keterpaduan kegiatan yang melibatkan interaksi antara pengguna layanan, pemberi layanan serta sistem atau fasilitas pendukung layanan. Oleh karenanya dalam memberikan pelayanan tersebut, kualitas menjadi tuntutan yang utama untuk memenuhi kepentingan pelanggan.

\section{Dimensi Kualitas Pelayanan}

Dalam perkembangan selanjutnya Berry dan Parasuraman (dalam Nasution 2004:56) menemukan bahwa dari sepuluh dimensi kualitas layanan tersebut dapat dirangkum menjadi lima dimensi pokok. Kelima dimensi pokok kualitas pelayanan 
(SERVQUAL) tersebut meliputi berikut ini :

a. Bukti langsung (Tangibles)

Meliputi fasilitas fisik, perlengkapan pegawai dan sarana komunikasi. Ini bisa dilihat secara langsung pada kantor dan pemberi layanan seperti fasilitas fisik perkantoran, peralatan komunikasi dan pegawai.

b. Keandalan (Reliability)

Yakni kemampuan memberikan pelayanan yang dijanjikan dengan segera, akurat dan memuaskan. Ini berarti bahwa dalam memberikan pelayanan aparat atau pegawai tidak menunda-nunda waktu dan tanpa penyimpangan bila dikaitkan dengan prosedur yang menjadi keinginan konsumen.

c. Daya tanggap (Responsiveness)

Yakni keinginan para staf atau pegawai untuk membantu konsumen untuk memberikan pelayanan yang tanggap. Ini berkaitan dengan penanganan yang diberikan terhadap keluhan-keluhan dari pelanggan.

d. Jaminan (Assurance)

Mencakup pengetahuan, kemampuan, kesopanan. Dan sifat yang dipercaya dimliki oleh para staf atau pegawai bebas dari bahaya, resiko dan keragu-raguan. Ini berarti bahwa seseorang pegawai meyakinkan konsumen terhadap pelayanan yang diberikan dan pegawai juga harus memiliki sifat sopan dan penuh keramahan dalam menghadapi konsumen.

e. Empati (Emphaty)

Meliputi kemudahan dalam melakukan hubungan, komunikasi yang baik, perhatian pribadi, dan memahami kebutuhan para pelanggan. Sikap ini bisa ditunjukan dengan komunikasi yang baik dari para pegawai, perhatian pribadi dan memahami dari kebutuhan para konsumen.

\section{Operasional Variabel}

Berdasarakan lima kriteria penentu kualitas jasa yang akan dianalisis untuk mengetahui seberapa jauh tanggapan pelanggan atas pelayanan pengangkutan sampah yang diterimanya, yaitu tingkat kepentingan dan tingkat kinerja. Maka variabel penelitian yang akan dioperasionalisasikan adalah sebagai berikut. 
Tabel 1. Operasional Variabel

\begin{tabular}{|c|c|}
\hline Dimensi & Indikator \\
\hline Bukti Langsung/ Tangibles & $\begin{array}{l}\text { 1. } \quad \text { Kendaraan angkutan sampah (Dumptruck) } \\
\text { 2. } \quad \text { TPS (Tempat Penampungan Sementara). }\end{array}$ \\
\hline Kehandal an/'Reliability & $\begin{array}{l}\text { 1. } \quad \text { Ketepatan waktu pengangkutan. } \\
\text { 2. } \quad \text { Kecepatan dalam pemuatan sampah. }\end{array}$ \\
\hline Kehandal an/'Reliability & $\begin{array}{l}\text { 1. Pelayanan yang selalu siap membantu/menolong. } \\
\text { 2. Kemampuan Organisasi/petugas untuk cepat tanggap } \\
\text { atas permasalahan yang timbul. }\end{array}$ \\
\hline Jaminan/Assurance & $\begin{array}{l}\text { 1. Pelayanan yang ramah selama proses pelayanan. } \\
\text { 2. Kemampuan atau tanggung jawab petugas dalam } \\
\text { penataan/pemuatan sampah. }\end{array}$ \\
\hline Empati/Emphaty & $\begin{array}{l}\text { 1. Memberikan pelayanan yang adil. } \\
\text { 2. Kesediaan untuk peduli atau antisipasi kebutuhan } \\
\text { pelanggan dalam proses pelayanan. }\end{array}$ \\
\hline
\end{tabular}

\section{METODE PENELITIAN}

Metode penelitian memegang peranan penting dalam kegiatan penelitian dan peneliti harus dapat menggunakan metode penelitian yang tepat dan sesuai dengan tujuan dan permasalahanya. Maka dalam penelitian ini akan digunakan metode penggabungan penelitian kualitatif dan kuantitatif. Hal ini sesuai dengan pendekatan "Logika Triangulasi" dari Brannen (dalam Kode, 2002:84) bahwa, "Temuan-temuan dari satu jenis studi dapat dicek temuan-temuan yang diperoleh dari jenis studi yang lain. Misalnya, hasil-hasil penelitian kualitatif dapat dicek pada studi kuantitatif. Tujuanya secara umum adalah untuk memperkuat kesahihan temuan-temuanya".

Dalam penelitian ini populasi yang akan diteliti adalah seluruh petugas kebersihan (swadaya) RT/RW yang melakukan pembuangan sampah atau mendapatkan layanan pengangkutan sampah dari DLH di TPS wilayah Kecamatan Patrang, Kecamatan Kaliwates, dan Kecamatan Sumbersari Kabupaten Jember.

Sampel yang akan diambil peneliti adalah petugas kebersihan (swadaya) RT/RW di wilayah Kecamatan Patrang, Kecamatan Kaliwates, dan Kecamatan Sumbersari Kabupaten Jember sebanyak 20 orang yang melakukan pembuangan sampah di TPS yang telah disediakan oleh Dinas Lingkunga Hidup dengan metode Sampling Purposive. Kriteria yang diambil oleh penulis adalah petugas sampah yang melakukan pemuatan sampah sebanyak 2 
kali pengangkutan.

Teknik pengumpulan data yang digunakan dalam penelitian ini adalah penyebaran kuesioner, dokumentasi, observasi dan wawancara. Penyebaran kuesioner dilakukan kepada petugas kebersihan (swadaya) RT/RW di wilayah Kecamatan Patrang, Kecamatan Kaliwates, dan Kecamatan Sumbersari Kabupaten Jember yang telah dijadikan sampel dalam penelitian ini. Studi dokumentasi dilakukan dengan mempelajari data-data yang bersifat data sekunder berupa buku, laporan-laporan dan lain sebagainya Adapun wawancara dilakukan personil yang di dalam organisasi seperti kepala dinas, kepala sub- dinas maupun kepada pegawai lainnya.Metode analisis data yang digunakan dalam penelitian ini meliputi tahap pengujian instrumen yang terdiri dari uji validitas dan uji reliabilitas, guna untuk menjadi alat ukur dalam kuesioner. Selanjutnya peneliti menggunakan metode Importance Performance Analysis (IPA) guna untuk mengetahui variabel tingkat kinerja dan variabel tingkat kepentingan pelanggan.

a. Uji Validitas

Uji Validitas dalam penelitian ini digunakan analisis item yaitu mengkorelasikan skor tiap butir, dengan skor total yang merupakan jumlah skor tiap butir. Uji validitas digunakan untuk mengukur sah atau valid tidaknya suatu kuesioner yang diperoleh $\mathrm{r}$ masih harus diuji signifikansinya dengan membandingkanya dengan tabel r. Butir pertanyaan dikatakan valid jika nilai $r$ hitung $>\mathrm{r}$ tabel atau nilai $\mathrm{p}<0,05$.

b. Uji Reliabilitas

Uji Reliabilitas menurut Siregar (2011:175) adalah untuk mengetahui sejauh mana hasil pengukuran tetap konsisten, apabila dilakukan pengukuran dua kali atau lebih terhadap gejala yang sama dengan menggunakan alat pengukur yang sama pula. Teknik pengukuran reliabilitas dalam penelitian ini menggunakan Alpha Cronbach. Teknik atau rumus ini dapat digunakan untuk menentukan apakah suatu instrument penelitian reliabel atau tidak.

Selanjutnya teknik perhitungan uji reliabilitas ini akan dilakukan secara otomatis menggunakan aplikasi SPSS 13.0. Suatu konstruk atau variabel dikatakan reliabel jika memberikan nilai Cronbach Alpha $>0.60$ (Sujarweni).

\section{c. Importance Performance Analysis}

Dalam menganalisa data penelitian ini digunakan metode deskriptif kualitatifkuantitatif, untuk menjawab rumusan masalah mengenai sejauh mana tingkat kepuasan pelanggan terhadap kinerja. Maka akan digunakan Metode Analisis Kepentingan dan Kinerja Kepuasan Pelanggan (Importance Performance Analisys) dari Martila dan James 
(dalam Nasution, 2004:124) bahwa, "jasa akan menjadi sesuatu yang bermanfaat apabila didasarkan pada kepentingan pelanggan dan kinerjanya bagi organisasi”. Artinya penyedia jasa seharusnya mencurahkan perhatianya pada hal-hal yang memang dianggap penting oleh pelanggan.

Berdasar pada pendapat diatas, maka dalam menilai 5 dimensi dengan 10 indikator kualitas pelayanan Pengangkutan Sampah DLH peneliti menggunakan Skala Likert untuk mengetahui seberapa jauh tanggapan pelanggan atas kualitas pelayanan yang diterimanya, yaitu tingkat kepentingan dan tingkat kinerja. Hal ini sesuai dengan pendapat Tjiptono (2002:99) bahwa, untuk mengukur harapan dan persepsi pelanggan dan kesenjangan yang ada dikualitas jasa, pengukuran dapat dilakukan dengan Skala Likert atau Semantik Diferensial, dimana responden tinggal memilih derajat kesetujuan/ketidaksetujuan atas pernyataan mengenai penyampaian kualitas jasa.

Tabel 2 Skala Likert

\begin{tabular}{|c|c|}
\hline Skala Jawaban & Skor \\
\hline Sangat Baik & 5 \\
\hline Baik & 4 \\
\hline Cukup Baik & 3 \\
\hline Kurang Baik & 2 \\
\hline Tidak Baik & 1 \\
\hline
\end{tabular}

(Sugiyono, 2012:94)

Berdasarkan hasil penilaian tingkat kepentingan dan hasil kinerja, maka akan dihasilkan suatu perhitungan mengenai tingkat kesesuaian atau tingkat kepuasan antara "tingkat kepentingan" dan "tingkat kinerja" oleh penyedia jasa.

Dalam penelitian ini terdapat 2 buah variabel yang diwakilkan oleh huruf $\mathrm{X}$ dan $\mathrm{Y}$, dimana $\mathrm{X}$ merupakan tingkat kinerja penyedia layanan yang dapat memberikan kepuasan para pelanggan, sedangkan Y merupakan tingkat kepentingan pelanggan.

Rumus yang digunakan Adalah

$T K i=-\mathrm{x} 100 \%$

(Nasution, 2004:125)

Di mana :

$\mathrm{TKi}=$ Tingkat kesesuaian responden

$\mathrm{Xi} \quad=\quad$ Skor penilaian kinerja penyedia jasa 
$\mathrm{Yi} \quad=\quad$ Skor penilaian kepentingan pelanggan

Selanjutnya untuk menghitung rata rata skor $(\mathrm{X})$ tingkat pelaksanaan atau tingkat kepuasan pelanggan seluruh faktor dan rata rata skor $(\mathrm{Y})$ tingkat kepentingan seluruh faktor yang memengaruhi kepuasan dimana seluruhnya ada 10 faktor, maka rumus selanjutnya :

$$
\frac{\overline{\overline{\mathrm{X}}}=\sum \underset{\mathrm{X}=1}{\mathrm{n}} \overline{\mathrm{X}}_{\mathrm{i}}}{\mathrm{K}}
$$

$$
\frac{\overline{\bar{Y}}=\sum_{1=1}^{n} \overline{\mathrm{Y}}_{\mathrm{i}}}{\mathrm{K}}
$$

(Nasution, 2004:126)

\section{ANALISIS HASIL PENELITIAN}

Obyek yang akan diteliti adalah TPS yang berada di wilayah Ibu Kota Kabupaten Jember yang telah disediakan oleh Dinas Lingkungan Hidup Kabupaten Jember. TPS adalah singkatan dari Tempat Penampungan Sementara, singkatan ini berdasarkan Peraturan Menteri Dalam Negeri Nomor 33 Tahun 2010 tentang Pedoman Pengelolaan Sampah. TPS adalah tempat ditampungnya sampah sebelum diangkut ke tempat pendauran ulang, pengolahan, dan/atau tempat pengolahan sampah terpadu.

1. Analisis Kualitas Layanan

Analisis Kualitas Layanan dilakukan dengan melihat kesenjangan (Gap) yang terjadi antara pelayanan yang diharapkan pelanggan dengan kinerja mengenai pelayanan yang diberikan oleh Dinas Lingkungan Hidup Kabupaten Jember. Hasil dari Kualitas Layanan dapat dilihat dari tabel berikut : 
Tabel 3 Kualitas Layanan

\begin{tabular}{|l|r|r|r|}
\hline Item & Importance & Performance Gap \\
\hline Tangible & 9.25 & 9.05 & -0.2 \\
\hline Reliability & 8.65 & 8.65 & 0 \\
\hline Responsiveness & 8 & 7 & -1 \\
\hline Assurance & 8.8 & 8.4 & -0.4 \\
\hline Emphaty & 9.05 & 8.25 & -0.8 \\
\hline
\end{tabular}

Sumber : Data Lampiran 3

Dari tabel diatas, diketahui bahwa kinerja dari Dinas Lingkungan Hidup Kabupaten Jember masih ada harapan yang di inginkan oleh pelanggan. Hal ini dapat dilihat dari keseluruhan gap antara kualitas dan kepuasan bernilai negative. Dengan gap terbesar ada pada Dimensi Daya Tanggap (Responsiveness) terdapat nilai gap sebesar -1 dan gap terkecil adalah 0 pada Dimensi Keandalan.

\section{Hasil Perhitungan Importance Performance Analysis}

Untuk menjawab permasalahan pokok dalam penelitian ini yaitu sejauhmana tingkat kepuasan pelanggan terhadap pelayanan Pengangkutan Sampah Dinas Lingkungan Hidup Kabupaten Jember, maka berikut akan dibahas secara garis besar mengenai variabelvariabel dengan berbagai indikator dalam penelitian.

Tabel 4 Variabel Tingkat Kinerja $(X)$

\begin{tabular}{|c|c|c|c|c|}
\hline Item & Variabel & Skor & $\begin{array}{l}\text { rata } \\
\text { rata }\end{array}$ & kategori \\
\hline \multirow[t]{2}{*}{ Tangibles } & $\mathrm{X} 1$ & 93 & \multirow{2}{*}{90.5} & \multirow{2}{*}{$\begin{array}{l}\text { Sanga } \\
\text { tinggi }\end{array}$} \\
\hline & $\mathrm{X} 2$ & 88 & & \\
\hline \multirow[t]{2}{*}{ Reliability } & X3 & 93 & \multirow{2}{*}{86.5} & \multirow{2}{*}{$\underset{\text { Sanggi }}{\text { Sanga }}$} \\
\hline & $\mathrm{X} 4$ & 80 & & \\
\hline \multirow[t]{2}{*}{ Responsiveness } & $\mathrm{X} 5$ & 70 & \multirow{2}{*}{70} & \multirow{2}{*}{ Tinggi } \\
\hline & X6 & 70 & & \\
\hline \multirow[t]{2}{*}{ Assurance } & $\mathrm{X7}$ & 68 & \multirow{2}{*}{84} & \multirow{2}{*}{$\begin{array}{l}\text { Sanga } \\
\text { tinggi }\end{array}$} \\
\hline & $\mathrm{X} 8$ & 100 & & \\
\hline \multirow[t]{2}{*}{ Emphaty } & X9 & 85 & \multirow{2}{*}{82.5} & \multirow{2}{*}{$\begin{array}{l}\text { Sanga } \\
\text { tinggi }\end{array}$} \\
\hline & $\mathrm{X} 10$ & 80 & & \\
\hline \multicolumn{3}{|c|}{ Skor rata rata } & 82.7 & $\begin{array}{l}\text { Sangat } \\
\text { tinggi }\end{array}$ \\
\hline
\end{tabular}

Berdasarkan data tabel diatas, tampak bahwa secara umum jawaban dari 20 orang responden untuk tingkat kualitas kinerja/penampilan pada 5 dimensi dan 10 indikator kualitas pelayanan dapat dikategorikan sangat tinggi yaitu mencapai skor rata rata 82,7 . 
Tabel 5 Variabel Tingkat Kepentingan (Y)

\begin{tabular}{|c|c|c|c|c|}
\hline Item & Variabel & Sko & $\begin{array}{l}\text { Rata } \\
\text { rata }\end{array}$ & Kategori \\
\hline \multirow[t]{2}{*}{ Tang ibles } & Y1 & 100 & \multirow{2}{*}{92.5} & \multirow{2}{*}{$\begin{array}{l}\text { Sangat } \\
\text { Tinggi }\end{array}$} \\
\hline & $\mathrm{Y} 2$ & 85 & & \\
\hline \multirow[t]{2}{*}{ Reliability } & Y3 & 90 & \multirow{2}{*}{86.5} & \multirow{2}{*}{$\begin{array}{l}\text { Sangat } \\
\text { Tinggi }\end{array}$} \\
\hline & Y4 & 83 & & \\
\hline \multirow[t]{2}{*}{ Responsiveness } & Y5 & 80 & \multirow{2}{*}{80} & \multirow{2}{*}{ Tinggi } \\
\hline & Y6 & 80 & & \\
\hline \multirow[t]{2}{*}{ Assurance } & Y7 & 88 & \multirow{2}{*}{91.5} & \multirow{2}{*}{$\begin{array}{l}\text { Sangat } \\
\text { Tinggi }\end{array}$} \\
\hline & Y8 & 95 & & \\
\hline \multirow[t]{2}{*}{ Emphaty } & Y9 & 88 & \multirow{2}{*}{90.5} & \multirow{2}{*}{$\begin{array}{l}\text { Sangat } \\
\text { Tinggi }\end{array}$} \\
\hline & Y10 & 93 & & \\
\hline \multicolumn{3}{|c|}{ Skor rata rata } & 88.2 & $\begin{array}{l}\text { Sangat } \\
\text { Tin }_{\text {ggi }}\end{array}$ \\
\hline
\end{tabular}

Dari data tabel diatas tampak bahwa secara umum jawaban 20 responden untuk tingkat Kepentingan pelanggan terhadap 5 dimensi dan 10 indikator kualitas pelayanan dapat dikategorikan sangat tinggi, yaitu mencapai total skor 88,2.

Tahapan yang dilakukan untuk menentukan kesesuaian antara tingkat kinerja dan tingkat kepentingan dapat digunakan rumus berikut :

$$
\begin{aligned}
& \text { Tki Total }=\frac{\Sigma X i}{\Sigma Y i} \times 100 \% \\
& \text { Tki Total }=\frac{827}{882} \times 100 \%
\end{aligned}
$$

Tki Total $=93,76 \%$ 
Keterangan :

Tki : Tingkat Kesesuaian

$\mathrm{Xi} \quad$ : Skor Penilaian Kinerja Penyedia Jasa

Yi : Skor Penilaian Kepentingan Pelanggan

Berdasarkan hasil perhitungan tingkat kesesuaian yaitu sebesar 93,76\% secara keseluruhan dapat disimpulkan bahwa kualitas Pelayanan Pengangkutan Sampah Dinas Lingkungan Hidup Kabupaten Jember berada pada kategori Sangat Baik.

Kemudian pada tahap selanjutnya adalah menganalisa kuadran, yaitu menghitung rata-rata penilaian dari variabel $\mathrm{X}$ dan variabel $\mathrm{Y}$ dengan rumus berikut :

$$
\begin{gathered}
\overline{\bar{X}}=\frac{\sum_{i=1}^{n} X}{k} \\
\frac{41,35}{10} \quad \overline{\bar{X}}=4,14 \\
\overline{\bar{Y}}=\frac{\sum_{i=1}^{n} Y}{k} \\
\frac{44,1}{10} \quad \overline{\bar{Y}}=4,41
\end{gathered}
$$

Dimana :

$\mathrm{X}=$ Skor rata-rata pelaksanaan

$\boldsymbol{Y}=$ Skor rata-rata tingkat kepentingan

$\mathrm{K}=$ Banyaknya faktor/atribut yang dapat mempengaruhi kepuasan pelanggan yaitu 10 faktor/atribut. 


\section{Diagram Kartesius}

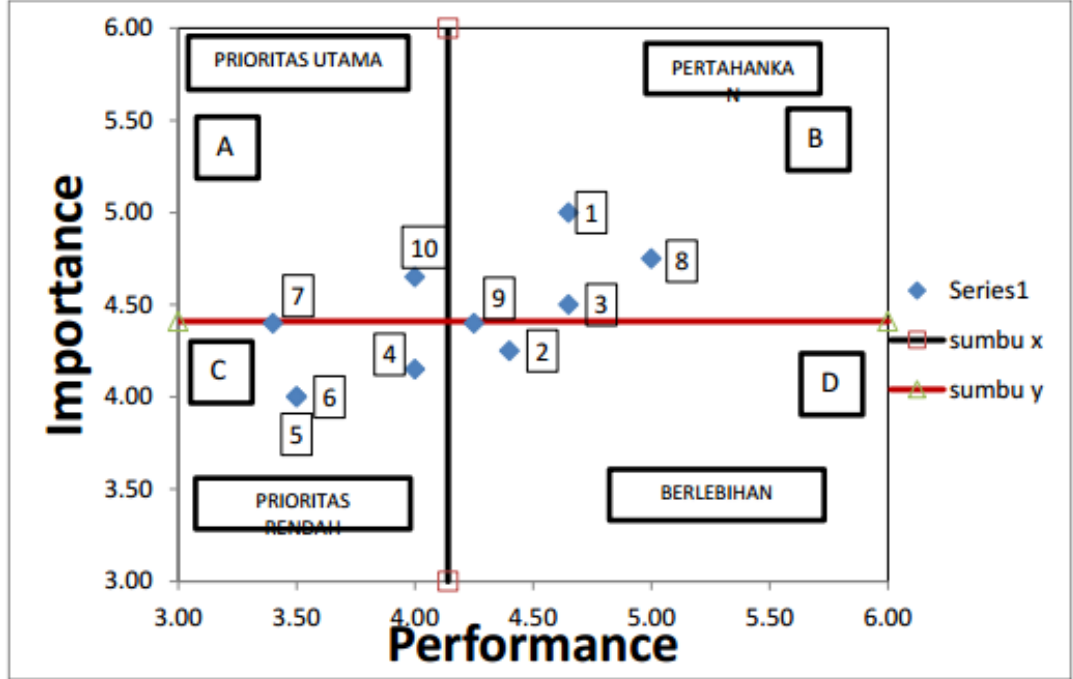

1. Kuadran I (Prioritas Utama)

Pernyataan-pernyataan yang berada pada Kuadran ini dianggap sangat penting oleh para pelanggan tetapi pelayananya yang kurang memuaskan sehingga Dinas Lingkungan Hidup perlu meningkatkan kualitas pelayanannya.

- Penyataan 7 : Keramahan dan Kejujuran petugas pelayanan sampah Dinas Lingkungan Hidup Kabupaten Jember.

- Pernyataan 10 : Mudah untuk dihubungi dan Komunikasi yang baik selama proses pengangkutan sampah.

Dengan kesimpulan Dinas Lingkungan Hidup Kabupaten Jember perlu memprioritaskan untuk memperbaiki kinerja pelayananya yang dianggap penting oleh pelanggan.

2. Kuadran II (Pertahankan Prestasi)

Pernyataan yang dianggap sangat penting bagi pelanggan dan juga kualitas pelayanan yang sangat memuaskan, sehingga Dinas Lingkungan Hidup Kabupaten Jember perlu mempertahankan kualitas pelayanannya.

- Pernyataan 1 : Penampilan kendaraan yang digunakan untuk melayani pengangkutan sampah. 
- Pernyataan 3 : Ketepatan waktu dalam pengangkutan sampah.

- Pernyataan 8 : Kemampuan dan Tanggung jawab petugas dalam menjamin keamanan sampah yang diangkut ke lokasi pembuangan akhir.

- Pernyataan 9 : Sikap adil dalam melayani dari petugas pengangkutan sampah.

Dapat disimpulkan pada pernyataan diatas, bahwa pelanggan sangat puas dalam pelayanan yang diberikan Dinas Lingkungan Hidup Kabupaten Jember. Oleh karenanya, Dinas Lingkungan Hidup Kabupaten Jember harus mempertahankan kualitas pelayananya.

3. Kuadran III (Prioritas Rendah)

Pernyataan yang dianggap tidak penting oleh pelanggan dan kualitas pelayanan yang kurang memuaskan.

- Pernyataan 4: Kecepatan dalam melayani pemuatan atau penuangan sampah.

- Pernyataan 5 : Ketanggapan Dinas Lingkungan Hidup Kabupaten Jember atau petugas dalam permasalahan yang timbul dalam pelayanan pengangkutan sampah.

- Pernyataan 6 : Ketanggapan Dinas Lingkungan Hidup Kabupaten Jember atau petugas terhadap keluhan yang disampaikan oleh pelanggan.

Dapat disimpulkan bahwa pelanggan merasa tidak puas terhadap pelayanan yang terdapat pada pernyataan ini, dan juga pelanggan menganggap tidak penting, tetapi perlu adanya perbaikan bagi Dinas Lingkungan Hidup Kabupaten Jember.

4. Kuadran IV (Berlebihan)

Pernyataan yang dianggap tidak penting oleh pelanggan namun pelayanannya sangat memuaskan.

- Pernyataan 2 : Kondisi Transferdepo yang digunakan untuk pemuatan sampah.

Dapat disimpulkan bahwa pelanggan merasa puas terhadap kinerja yang diberikan oleh Dinas Lingkungan Hidup Kabupaten Jember.

\section{SIMPULAN}

Berdasarkan hasil pembahasan yang telah dikemukakan, dapat disimpulkan sebagai berikut: 
1. Dimensi kualitas layanan yang memenuhi kepuasan pelanggan pengangkutan sampah Dinas Lingkungan Hidup Kabupaten Jember.

\section{a. Kehandalan (Reliability)}

Dimensi Kehandalan mencapai skor kesenjangan terendah yaitu 0 dan dikategorikan sangat memuaskan. Angka tersebut didukung oleh pelaksanaan indikator pelayanan yang tepat waktu dan kecepatan dalam pemuatan sampah yang dikategorikan sangat memuaskan.

b. Bukti Langsung (Tangibles)

Dimensi Bukti Langsung mencapai skor kesenjangan yaitu -0,2 yang data dikategorikan sangat memuaskan. Angka tersebut didukung oleh pelaksanaan indikator keberadaan transferdepo atau sarana pembuangan sampah yang dianggap tidak penting oleh pelanggan dan keberadaan Dumptruck atau sarana pengangkutan sampah yang dianggap sangat memuaskan.

\section{c. Jaminan (Assurance)}

Dimensi Jaminan mencapai skor kesenjangan yaitu $-0,4$ yang dapat dikategorikan sangat memuaskan. Angka tersebut didukung oleh pelaksanaan indikator pelayaan yang ramah dari petugas dan tanggung jawab petugas dalam pemuatan sampah dengan kategori yang sangat memuaskan.

d. Empati (Emphaty)

Dimensi Empati mencapai skor kesenjangan -0,8 yang dapat dikategorikan cukup baik. Angka tersebut didukung oleh indikator pelayanan yang adil dan kesediaan petugas terhadap kebutuhan pelanggan yang dianggap sangat memuaskan.

2. Dimensi kualitas layanan yang harus ditingkatkan untuk upaya peningkatan kepuasan pelanggan pengangkutan sampah.

\section{a. Daya Tanggap (Responsiveness)}

Dimensi Daya Tanggap merupakan dimensi urutan terakhir karena mencapai skor kesenjangan yang dapat dikatakan tinggi yaitu -1 dan dikategorikan tidak memuaskan. Angka tersebut disebabkan dari pelaksanaan indikator pelayanan yang siap membantu dan daya tanggap Dinas Lingkungan Hidup Kabupaten Jember dalam mengatasi permasalahan yang timbul dalam proses pelayanan dikatakan kurang memuaskan.

Dapat diketahui bahwa atribut dimensi yang dikatakan tidak dapat memuaskan pelanggan yaitu terdapat pada item : 
1. Pernyataan 4 : Kecepatan dalam melayani pemuatan atau penuangan sampah.

2. Pernyataan 5 : Ketanggapan Dinas Lingkungan Hidup Kabupaten Jember atau petugas dalam permasalahan yang timbul dalam pelayanan pengangkutan sampah.

3. Pernyataan 6 : Ketanggapan Dinas Lingkungan Hidup Kabupaten Jember atau petugas terhadap keluhan yang disampaikan oleh pelanggan.

Dengan demikian kualitas pelayanan Pengangkutan Sampah Dinas Lingkungan Hidup Kabupaten Jember masih perlu ditingkatkan lagi sehingga mendapat tingkat kesenjangan yang lebih rendah lagi atau mencapai tingkat kualitas yang lebih tinggi lagi, sesuai dengan kebutuhan atau kepentingan pelanggan demi tercapainya tingkat kepuasan dan tingkat kinerja yang lebih tinggi lagi.

\section{DAFTAR PUSTAKA}

Aprimawati, Baiq .2016. Kebijakan Pemerintah Daerah Dalam Meningkatkan Kualitas Pelayanan Persampahan Dinas Pengelolaan Lingkungan Hidup Dan Keindahan Kota Makasar. Jurnal Ilmu Pemerintahan Widyapraja. Vol XLII No. 2.

Brannen, Julia. 2002. Memadu Metode Penelitian Kualitatif dan Kuantitatif. Yogyakarta : Pustaka Belajar.

Cooper PD, 1979. Health Care Marketing, ASPEN System Corporations, Maryland.

Hakim, Ujang L. Dkk. 2018. Kualitas Pelayanan Pengangkutan Sampah Oleh Dinas Lingkungan Hidup Kota Tasikmalaya. Jurnal Bernologits Vol 3. No 1.

Hidayat, Agus Supriyanto. Pengaruh Koordinasi Internal Dan Pengawasan Preventif Terhadap Kinerja Pegawai Pengangkutan Sampah. Universitas Nurtanio Bandung. https://www.cendananews.com/2018/11/kesadaran-masyarakat-masih-rendah-sampah-dijember- menggunung.html. Diakses pada 11 oktober 2020 pukul 21.57 wib. https://bulelengkab.go.id/detai/artikel/tpa-adalah-tempat-pemrosesan-akhir-bukan-tempatpembuangan-akhir-70. Diakses pada 16 oktober 2020 pukul 04.05 wib.

Juhriatna. Dkk. 2014. Pengaruh Kinerja Pegawai Pemeliharaan Kendaraan Terhadap Kualitas Jasa Pelayanan Pengangkutan Sampah. Jurnal Sosial Humaniora ISSN 2087-4928 Volume 5 Nomor 1.

Kartono, Kartini. 1996. Pengantar Metodologi Riset Sosial. Bandung : Mandar Maju.

Koentjoroningrat. 1991. Metodologi Penelitian Masyarakat. Jakarta : Gramedia.

Kotler dan Keller. 2009. Manajemen Pemasaran. Jilid I. Edisi ke 13. Jakarta: Erlangga 
Moenir. 2002. Manajemen Pelayanan Umum Di Indonesia. Jakarta : PT. Bumi Aksara.

Muksin, Mumuh. Dkk. 2020. Analisis Kualitas Pelayanan Dalam Tata Kelola Sampah Di Kabupaten Sumedang. Jurnal Ilmiah Manajemen. Vol 1. No 1.

Nasution, M.Nur. 2004. Manajemen Jasa Terpadu (Total Service Manajemen). Bogor : Ghalia Indonesia.

Nasution, 1992. Berbagai Pendekatan Dalam Proses Belajar Mengajar. Jakarta: Bumi Aksara

Pamungkas, Gayuh Fitri. 2018. Evaluasi Pengelolaan Sampah Dengan Metode Importance Performance Analysis (IPA) Dalam Strategi Pengembangan Teknik Operasional Pengelolaan Sampah Kota Surakarta. Jurusan Teknik Industri Fakultas Teknik Universitas Muhammadiyah Surakarta.

Ramadan, Bimasatyaji Surya. Dkk. 2017. Optimasi Sistem Pengangkutan Sampah Kecamatan Jati Kabupaten Kudus Jawa Tengah. Jurnal Presipitasi : Media Komunikasi dan Pengembangan Teknik Lingkungan. Vol 16 No 1.

Rasyid, MR. 1997. Pembangunan Pemerintahan Indonesia Memasuki Abad 21, Pidato Pengukuhan Guru Besar Tetap Ilmu Politik pada IIP. Jakarta.

Riduwan. 2002. Skala Pengukuran Variabel-variabel Penelitian. Bandung: Alfa Beta Setyabudi, Albertus L. 2018. Analisa Kepuasan Masyarakat Terhadap Pelayanan Pengangkutan Sampah PT. Sacor Mandiri Jaya Di Komplek Perumahan Greentown Bengkong. Jurnal Industri Kreatif (JIK). Sekolah Tinggi Teknik Ibnu sina. Batam. Vol 2. No 1. ISSN : 2597-8950.

Sihombing, Chandra. 2009. Analisis Faktor Determinan Kualitas Pelayanan Persampahan Di Kota Pematangsiantar. Dinas Lingkungan Hidup dan Kebersihan Kota Pematangsiantar.

Singarimbun dkk, 1989. Metodologi Penelitian Survey. Jakarta : LP3ES.

Sudaryono. 2016. Manajemen Pemasaran Teori Dan Implementasi. Yogyakarta: ANDI

Sugiyono. 2000. Metodologi Penelitian Administrasi. Bandung : CV. Alfabeta.

2003. Metode Penelitian Bisnis. Bandung : Pusat Bahasa Depdiknas.

2012. Metode Penelitian Kuantitatif, Kualitatif Dan R \& D. Bandung : Alfa Beta

Susnawati, Tuti. 2018. Pelaksanaan Kualitas Pelayanan Kebersihan Oleh Dinas Lingkungan Hidup Dan Kebersihan Kabupaten Pangandaran Dalam Menunjang Wisata Kelas Dunia. Jurnal Moderat Volume 4 No 3.

Tjiptono, Fandy. 2002. Manajemen Jasa. Yogyakarta : Andi. 